\title{
Simulation of Water-Surface Elevations for a Hypothetical 100-Year Peak Flow in Birch Creek at the Idaho National Engineering and Environmental Laboratory, Idaho
}

By Charles Berenbrock and L.C. Kjelstrom

U.S. GEOLOGICAL SURVEY

Water-Resources Investigations Report 97-4083

Prepared in cooperation with the

U.S. Department of Energy

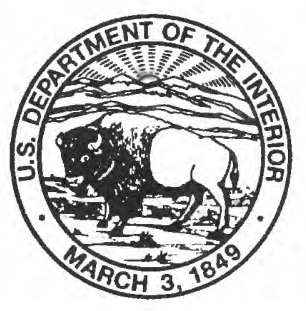




\title{
U.S. DEPARTMENT OF THE INTERIOR \\ BRUCE BABBITT, Secretary
}

U.S. GEOLOGICAL SURVEY

Gordon P. Eaton, Director

The use of firm, trade, and brand names in this report is for identification purposes only and does not constitute endorsement by the U.S. Geological Survey.

For additional information write to:

Copies of this report can be purchased from:

District Chief

U.S. Geological Survey

230 Collins Road

Boise, ID 83702-4520

\author{
U.S. Geological Survey \\ Information Services \\ Box 25286 \\ Federal Center \\ Denver, CO 80225
}




\section{CONTENTS}

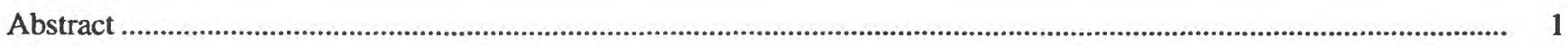

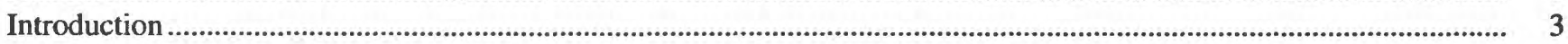

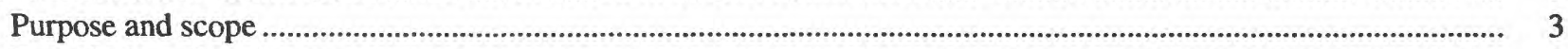

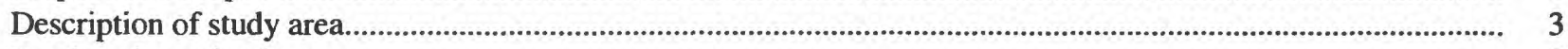

Previous investigations.......................................................................................................................................... 5

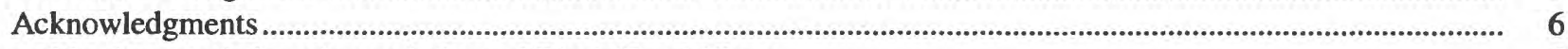

Geomorphic characteristics of gravel pits and Birch Creek Playa.................................................................................. 6

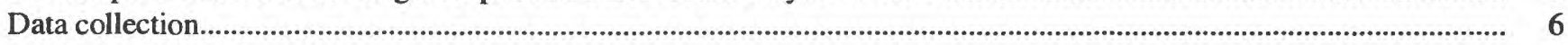

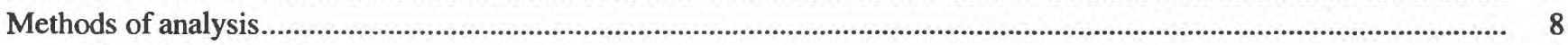

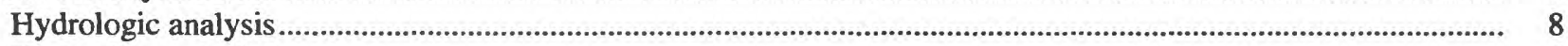

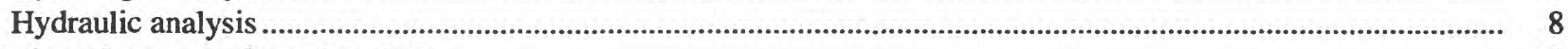

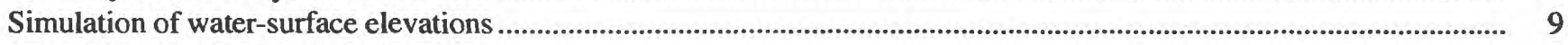

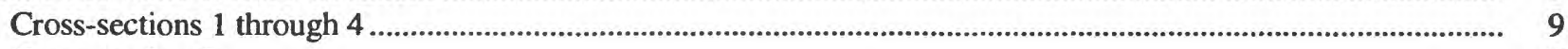

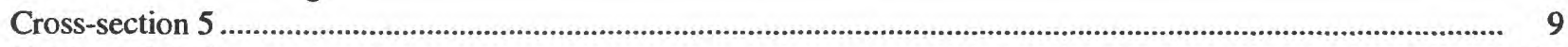

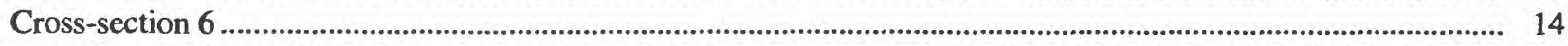

Total flow in channel having lowest streambed elevation................................................................................. 14

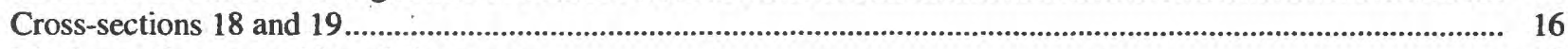

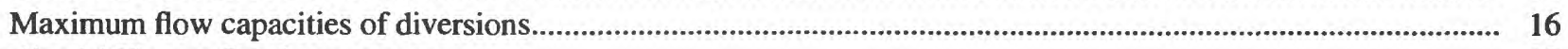

Generalized 100-year flood-prone areas ....................................................................................................................... 17

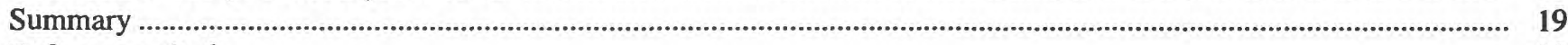

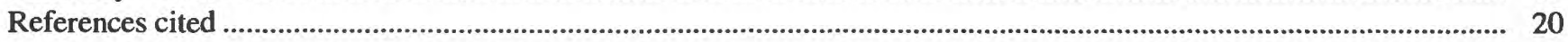

\section{FIGURES}

1. Map showing locations of study area, Birch Creek Basin, and part of the Idaho National Engineering and

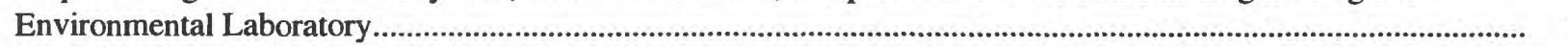

2. Map showing locations of Birch Creek, cross sections, diversion channels, gravel pits, and Birch Creek Playa ..... 4

3. Graph showing relations among elevation of land surface, depth below a given elevation, surface area, and volume of Birch Creek Playa ........................................................................................................................ 7

4. Graphs showing water- and land-surface elevations, Birch Creek................................................................... 10

5. Map showing peak flow in Birch Creek, maximum capacities of diversions, and volumes of gravel pits 2 and $3 \ldots 15$

6. Map showing generalized flood-prone areas resulting from a 100-year peak flow in Birch Creek.......................... 18

\section{TABLES}

1. Selected geomorphic characteristics of gravel pits 2 and 3 and Birch Creek Playa ............................................. 6

2. Maximum flow capacities of diversions on Birch Creek ............................................................................ 16 


\section{CONVERSION FACTORS AND VERTICAL DATUM}

\begin{tabular}{rcl}
\hline Multiply & \multicolumn{1}{c}{ By } & To obtain \\
acre & 0.004047 & square kilometer \\
acre-foot $(\mathrm{acre}-\mathrm{ft})$ & 1,233 & cubic meter \\
cubic foot per second $\left(\mathrm{ft}^{3} / \mathrm{s}\right)$ & 0.02832 & cubic meter per second \\
cubic foot per second per mile $\left[\left(\mathrm{ft}^{3} / \mathrm{s}\right) / \mathrm{mil}\right]$ & 0.0176 & cubic meter per second per square kilometer \\
foot $(\mathrm{ft})$ & 0.3048 & meter \\
foot per mile $(\mathrm{ft} / \mathrm{mi})$ & 0.1894 & meter per kilometer \\
mile $(\mathrm{mi})$ & 1.609 & kilometer \\
\hline
\end{tabular}

Sea level: In this report, "sea level" refers to the National Geodetic Vertical Datum of 1929 (NGVD of 1929)—a geodetic datum derived from a general adjustment of the first-order level nets of both the United States and Canada, formerly called Sea Level Datum of 1929. 


\title{
Simulation of Water-Surface Elevations for a
}

\section{Hypothetical 100-Year Peak Flow in Birch Creek at the Idaho National Engineering and Environmental Laboratory, Idaho}

\author{
By Charles Berenbrock and L.C. Kjelstrom
}

\section{ABSTRACT}

Delineation of areas at the Idaho National Engineering and Environmental Laboratory that would be inundated by a 100-year peak flow in Birch Creek is needed by the U.S. Department of Energy to fulfill flood-plain regulatory requirements. Birch Creek flows southward about 40 miles through an alluvium-filled valley onto the northern part of the Idaho National Engineering and Environmental Laboratory site on the eastern Snake River Plain. The lower 10-mile reach of Birch Creek that ends in Birch Creek Playa near several Idaho National Engineering and Environmental Laboratory facilities is of particular concern. Birch Creek is highly braided, and many anthropogenic features in the study area affect flood hydraulics and flow.

Dikes surround two of the facilities in and around the playa. At the elevation of the top of the dikes, Birch Creek Playa has a volume of 21,600 acre-feet, greater than the volume of 13,000 acre-feet that would be generated by the hypothetical 100-year peak flow. The watersurface elevation resulting from a volume of 13,000 acre-feet is about 2 feet lower than the elevation of the dikes; therefore, no flooding of the facilities would be expected from the hypothetical 100-year peak flow.

Twenty-six channel cross sections were surveyed to develop and apply a hydraulic model to simulate water-surface elevations for a hypothetical 100-year peak flow in Birch Creek. Model sim- ulation of the 100-year peak flow (700 cubic feet per second) in reaches upstream from State Highway 22 indicated that flow was confined within channels even when all flow was routed to one channel. Where the highway crosses Birch Creek, about 315 cubic feet per second of water was estimated to move downstream-115 cubic feet per second through a culvert and 200 cubic feet per second over the highway. Simulated water-surface elevation at this crossing was 0.8 foot higher than the elevation of the highway. The remaining 385 cubic feet per second flowed southwestward in a trench along the north side of the highway. Flow also was simulated with the culvert removed. Only the maximum flow capacities were determined for diversion channels because they probably would be at full capacity during peak flow.

The exact location of flood boundaries on Birch Creek could not be determined because of the highly braided channel and the many anthropogenic features (such as the trench, highway, and diversion channels) in the study area that affect flood hydraulics and flow. Because flood boundaries could not be located exactly, only a generalized flood-prone map was developed. Upstream from Highway 22, peak flows were confined within the braided channels. At Highway 22 and downstream, flows spread out, probably due to the anthropogenic features. If the anthropogenic features were not present, peak flows probably would be confined within the braided channels of Birch Creek. 


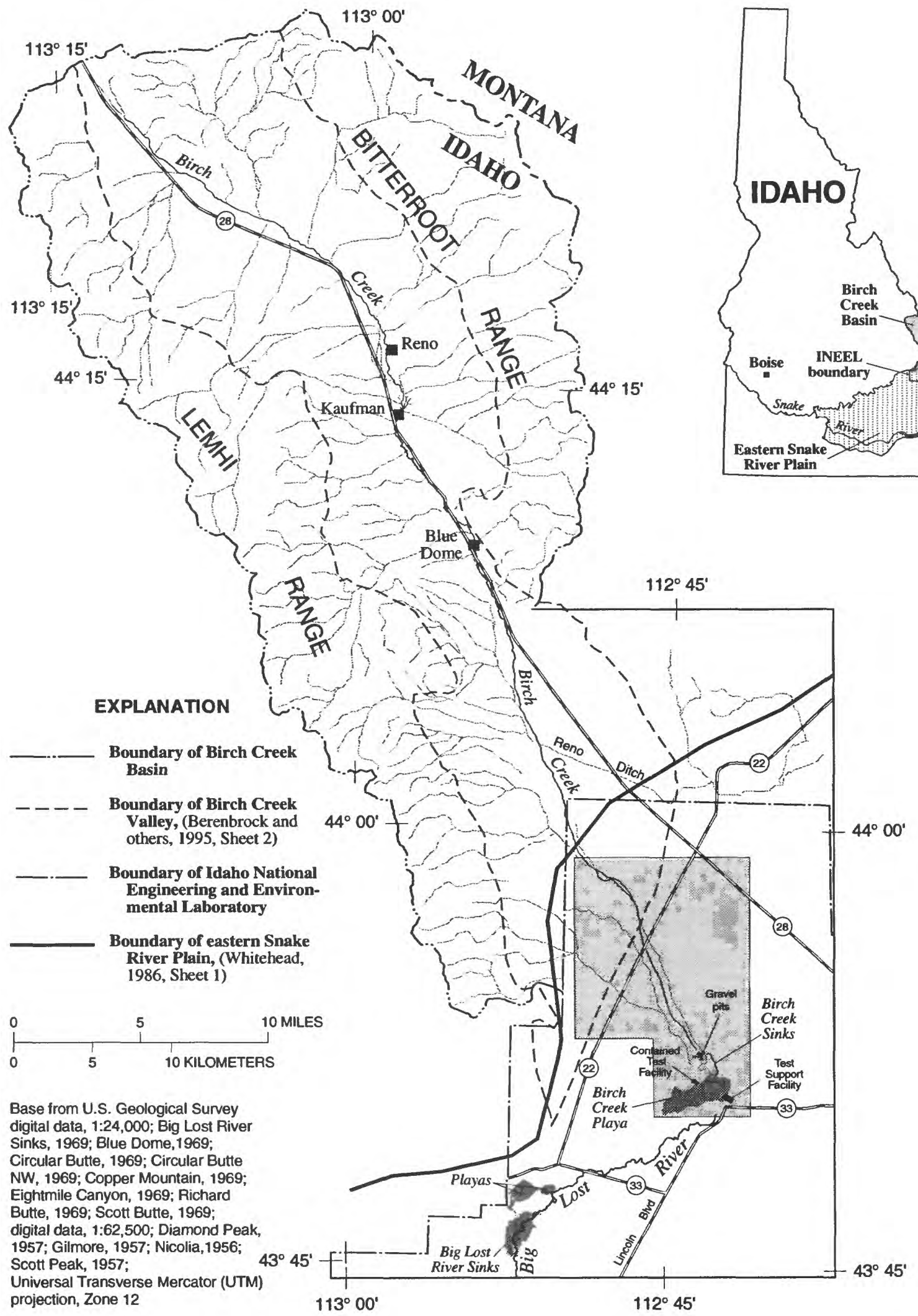

Figure 1. Locations of study area, Birch Creek Basin, and part of the Idaho National Engineering and Environmental Laboratory. 


\section{INTRODUCTION}

Birch Creek flows southward about $40 \mathrm{mi}$ through an alluvium-filled valley to the eastern Snake River Plain (fig. 1). The Lemhi and Bitterroot Ranges that border the valley are 9,000 to $12,000 \mathrm{ft}$ above sea level. Precipitation in the mountains supplies most water in the valley. Before reaching the eastern Snake River Plain, some flow in Birch Creek is diverted for irrigation and power generation. However, during nonirrigation seasons, this flow is returned to Birch Creek by a canal that runs from the powerplant to a gravel pit just below Highway 22 (fig. 2). In most years, water in Birch Creek infiltrates into the ground or evaporates upon reaching the plain. When water supply is adequate, Birch Creek flows onto the northern part of the Idaho National Engineering and Environmental Laboratory (INEEL) site and terminates in the Birch Creek Playa. At the INEEL, several diversion channels route water to gravel pits to prevent water from reaching INEEL facilities in and around the playa. Because of diversions and infiltration losses, water in Birch Creek rarely reaches Birch Creek Playa. However, in 1969, about 3,500 acre-ft of water accumulated in the playa. Although flow of that magnitude is rare, the extent of possible flooding at the INEEL needs to be determined to fulfill flood-plain regulatory requirements for emergency planning, environmental studies, construction of proposed facilities, and control of flood damage. In 1994, the U.S. Department of Energy (USDOE) at the INEEL entered into a cooperative agreement with the U.S. Geological Survey (USGS) to develop and implement 100-year peak flow studies.

\section{Purpose and Scope}

The purpose of this study was to delineate the areal extent of possible flooding at the INEEL resulting from peak flow in Birch Creek having a recurrence interval of 100 years. The Birch Creek flood plain was delineated in three phases. In phase one, Kjelstrom and Berenbrock (1996) estimated 100-year peak flows and flow volumes for the Big Lost River and Birch Creek. In phase two, twenty-six cross sections were surveyed within the boundary of the INEEL. The cross sections provided data needed in phase three to develop a floodplain model of Birch Creek and to determine flow capacity of diversions. The model simulated a hypothetical 100-year peak flow in Birch Creek and calculated corresponding water-surface elevations along surveyed cross sections at the INEEL. The simulated water-surface elevations then were used to delineate the areal extent of flooding caused by the hypothetical 100 -year peak flow.

This report presents the results of phases two and three and includes a discussion of the effects of State Highway 22, the culvert under State Highway 22, a tributary channel to Birch Creek, and diversion channels on streamflow. Geomorphic characteristics of gravel pits and Birch Creek Playa, ultimate sumps for high flows, also are described.

\section{Description of Study Area}

The study area is a 10-mi reach of Birch Creek that ends in Birch Creek Playa at the northern part of the INEEL site (fig. 1). Several INEEL facilities are located in and around Birch Creek Playa. The two main ones are Test Support Facility (TSF) and Contained Test Facility (CTF). In the study area, Birch Creek is an ephemeral stream and is highly braided. South of State Highway 22 , it broadens to about $1 \mathrm{mi}$ in width (fig. 2). These stream channels are shallow and water moves rapidly during high flow. Upstream from diversion channel A (fig. 2), Birch Creek crosses southwest-sloping alluvial fans that formed at the base of the Bitterroot Range. Where State Highway 22 crosses Birch Creek, elevation of the streambed is about $75 \mathrm{ft}$ higher than it is $1.5 \mathrm{mi}$ to the southwest. Slope of the streambed 3 to $4 \mathrm{mi}$ upstream from State Highway 22 is about $60 \mathrm{ft} / \mathrm{mi}$, is $56 \mathrm{ft} / \mathrm{mi}$ at Highway 22, and is $45 \mathrm{ft} / \mathrm{mi}$ at diversion channel A. Downstream from diversion channel A, the streambed slopes gently toward Birch Creek Playa, a dried lake basin, which has the lowest elevation in the study area, $4,763.6 \mathrm{ft}$. Streambed slope between diversion channel A and cross-section 14 (fig. 2) is about $40 \mathrm{ft} / \mathrm{mi}$; slope between cross-section 14 and gravel pits 2 and 3 is about $30 \mathrm{ft} / \mathrm{mi}$. Between gravel pits 2 and 3 and Birch Creek Playa is an area called Birch Creek Sinks, where streambed slope is about $10 \mathrm{ft} / \mathrm{mi}$. Water entering the sinks usually infiltrates into the ground. Niccum (1973, p. 15-16) noted that water had entered Birch Creek Playa about four times since the 1890's.

Bed material in Birch Creek consists largely of coarse sand, gravel, and cobbles that are mined from the three gravel pits. Gravel pit 1 is composed largely of gravel, whereas gravel pit 3 is composed of coarse sand and some gravel. Gravel and sand are highly transmis- 


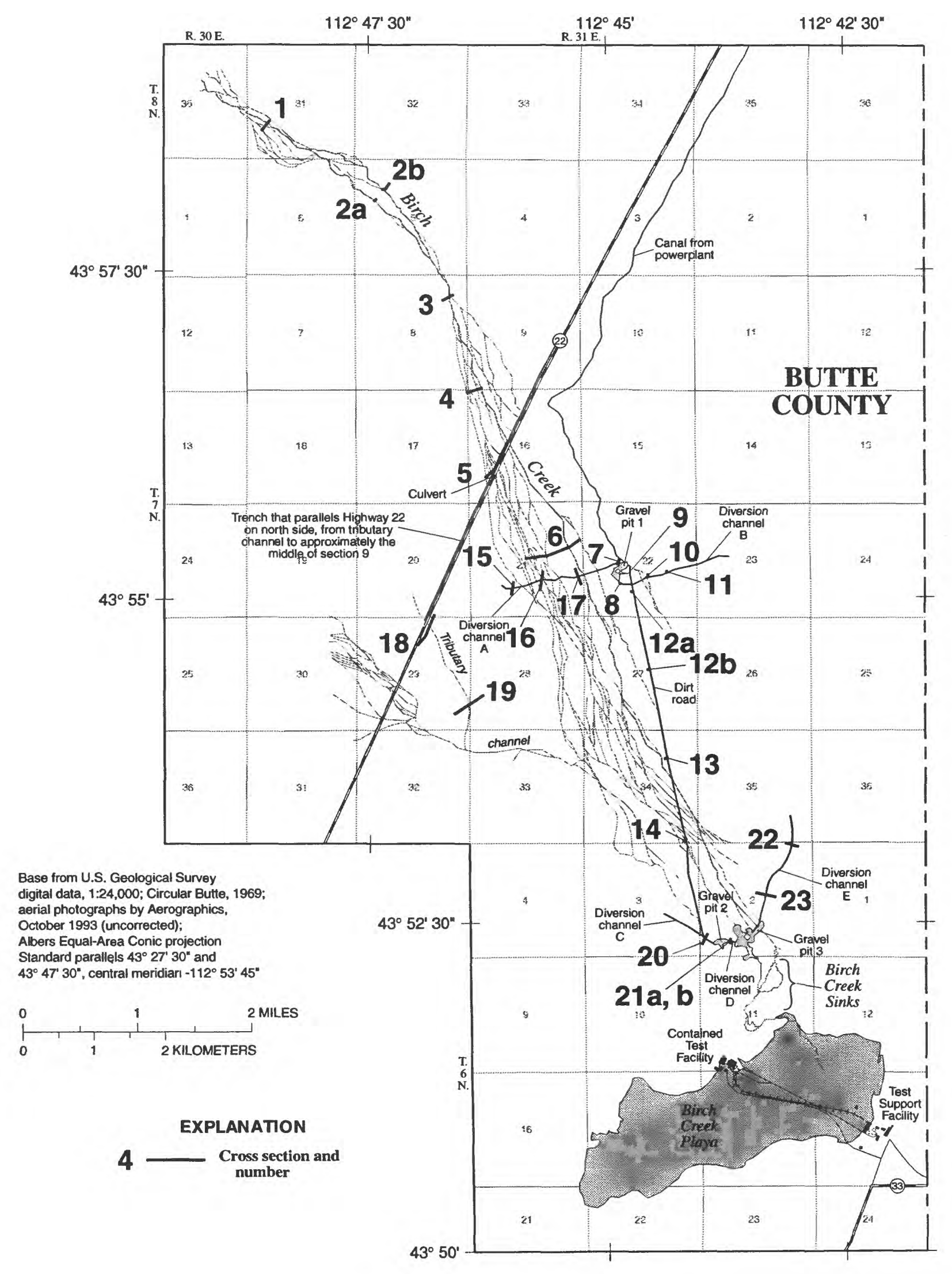

Figure 2. Locations of Birch Creek, cross sections, diversion channels, gravel pits, and Birch Creek Playa. 
sive and permit rapid infiltration of water. Channel infiltration tests on Birch Creek near Blue Dome (fig. 1) have been conducted by the USGS since the 1980's. Tests indicate that infiltration averages about $4\left(\mathrm{ft}^{3} / \mathrm{s}\right) / \mathrm{mi}$; the maximum rate exceeds $10\left(\mathrm{ft}^{3} / \mathrm{s}\right) / \mathrm{mi}$ when streamflow is about $70 \mathrm{ft}^{3} / \mathrm{s}$. Niccum (1973) noted that flows decreased downstream during the latter part of the 1969 flood, especially south of State Highway 22. Usually, Birch Creek does not flow beyond Birch Creek Sinks; therefore, no infiltration tests have been done in this area. Because materials underlying Birch Creek Sinks are similar to those underlying Big Lost River Sinks (Whitehead, 1986, sheet 1), similar infiltration rates might be expected. Bennett (1990) determined that the largest infiltration losses along the Big Lost River were at Big Lost River Sinks, where the maximum loss was $28\left(\mathrm{ft}^{3} / \mathrm{s}\right) / \mathrm{mi}$. Infiltration rates might be lower in Birch Creek Playa, which is underlain by low-permeability silt and clay.

Riparian vegetation in the study area is mainly sagebrush and grass; vegetation growth increases near Birch Creek. Several miles north of Highway 22, cottonwood trees grow along the stream. Sparse grasses grow on Birch Creek Playa.

Many anthropogenic features in the Birch Creek flood plain affect flood hydraulics and flow. State Highway 22 crosses Birch Creek near the middle of the study reach (fig. 2). A single, corrugated-steel-arch culvert, $3.25 \mathrm{ft}$ high, $4.8 \mathrm{ft}$ wide, and $65 \mathrm{ft}$ long, allows water to move under the highway. The top of the culvert is about $2.3 \mathrm{ft}$ below the highway surface, which is at an elevation of 4,999.7 ft. During peak flow, water that does not pass through the culvert or over the highway flows southwestward in a trench that parallels the highway. Water in the trench is intercepted by channels of a tributary to Birch Creek about $1.5 \mathrm{mi}$ to the southwest in sec. 29, T. 7 N., R. 31 E. (fig. 2). There is no culvert or bridge where these channels intersect Highway 22 to permit water movement under the highway.

About 1 mi south of State Highway 22, diversion channel A crosses Birch Creek and its flood plain. The 1-mi-long channel was dug in April 1969, just before the 1969 flood. The channel diverts streamflow eastward to gravel pit 1 (fig. 2). The gravel pit stores floodwater, which then infiltrates into the ground. A channel from the powerplant that receives water from Birch Creek by way of Reno Ditch (fig. 1) enters gravel pit 1 from the north. Maximum flow in this channel is about $75 \mathrm{ft}^{3} / \mathrm{s}$; this channel has water only during the nonirrigation season. The outlet of gravel pit 1 , diversion chan- nel $B$ at the southern end of the pit, diverts water $1 \mathrm{mi}$ to the east. Diverted water spreads out and infiltrates into the ground.

A 3.5-mi-long, southeast-trending dirt road, originating on the east side of gravel pit 1 , crosses diversion channel B and ultimately crosses all channels of Birch Creek (fig. 2). During peak flow, embankments cause water to flow down the road, in the direction of CTF, to diversion channel $\mathrm{C}$ and gravel pit 2. Overflow from gravel pit 2 moves to gravel pit 3 through diversion channel D. During peak flow, gravel pit 3 also receives water that might be in Birch Creek channels southeast of the dirt road and from diversion channel E. Overflow from gravel pit 3 would move southward into Birch Creek Sinks and, ultimately, into Birch Creek Playa.

Dikes with a top elevation of $4,786.5 \mathrm{ft}$ were constructed around the facilities at TSF and CTF in March 1969. Niccum (1973, p. 13, fig. 3B-3) indicated that, with dikes at an elevation of $4,786.5 \mathrm{ft}$, storage capacity of Birch Creek Playa would be about 13,000 acre-ft; with dikes at $4,790 \mathrm{ft}$, storage capacity would be about 28,000 acre-ft. The 1969 flood caused about 3,500 acre$\mathrm{ft}$ of water to accumulate in the playa (Niccum, 1973, p. 12-13). The resulting water-surface elevation of 4,782.2 ft would not have caused flooding at CTF because the floor at CTF is $7.8 \mathrm{ft}$ higher at an elevation of $4,790 \mathrm{ft}$. However, the floor of the CTF escape tunnel entrance, elevation $4,782.3 \mathrm{ft}$, probably would have been flooded were the dikes not present.

\section{Previous Investigations}

The first reported occurrence of streamflow reaching Birch Creek Playa was in 1894 (Nace and others, U.S. Geological Survey, written commun., 1959). Streamflow also reached the playa several times between 1900 and 1910 and again in 1969 (Niccum, 1973, p. 16). Niccum (1973) also discussed other floods in Birch Creek, flood control structures, and Birch Creek Playa. He estimated the magnitude and frequency of floods in relation to the potential for flooding at the INEEL. Koslow (1984) determined flood-frequency relations at three streamflow-gaging stations, the probable maximum flood based on a probable maximum storm, flooding from local snowmelt, and flooding potential of Birch Creek Playa. 


\section{Acknowledgments}

Appreciation is extended to Ken Beard, Lockheed Martin Idaho Technologies Company at the INEEL, who obtained horizontal and vertical control data by use of a Global Positioning System (GPS) and converted the data for our use. Appreciation also is extended to Sabrina A. Nicholls and Susan E. Moore, USGS, for their assistance in surveying cross sections.

\section{GEOMORPHIC CHARACTERISTICS OF GRAVEL PITS AND BIRCH CREEK PLAYA}

To understand the hydrology of Birch Creek in the study area, it was necessary to define geomorphic characteristics of the gravel pits and Birch Creek Playa. Because the pits and playa seldom contain water, areal and volumetric data were calculated as the difference between hypothetical water-surface elevation at fullpool capacity and land-surface elevation. The maximum water-surface elevation in the gravel pits at fullpool capacity was estimated by determining the elevation of their outlet. Land-surface elevations were obtained from digital elevation models (DEM's). DEM's are records of land-surface elevation and were digitized by Aerial Mapping, Inc. (Wayne Eskridge, Aerial Mapping, Inc., written commun., 1996) on a 19.7-ft (6-meter) spacing (longitudinally and latitudinally) from 1:10,000-scale aerial photographs. The DEM's were brought into a geographic information system (GIS) to compute surface area and volumetric data.

Selected geomorphic characteristics of gravel pits 2 and 3 and Birch Creek Playa are listed in table 1. Characteristics were not defined for gravel pit 1 because DEM data were not available for that area, no reliable estimates could be obtained from topographic maps, and gravel pit 1 is much smaller than gravel pit 2 , so its hydrologic effects were considered insignificant.

The dikes surrounding TSF and CTF are at an elevation of $4,786.5 \mathrm{ft}$. At that elevation, the surface area of water in the playa is 5,900 acres and the volume is 21,600 acre- $\mathrm{ft}$ (fig. 3), greater than the volume of 13,000 acre- $\mathrm{ft}$ that would be generated by the 100 -year peak flow (Kjelstrom and Berenbrock, 1996). A volume of 13,000 acre- $\mathrm{ft}$ results in a water-surface elevation of $4,784.5 \mathrm{ft}$, which is $2 \mathrm{ft}$ lower than the elevation of the dikes. At an elevation of $4,788 \mathrm{ft}$, the surface area of water in the playa is 8,140 acres and the volume is 31,800 acre-ft (table 1). An elevation of 4,788 ft was
Table 1. Selected geomorphic characteristics of gravel pits 2 and 3 and Birch Creek Playa

[Locations shown in figure 2]

\begin{tabular}{lrrrr}
\hline \multicolumn{1}{c}{ Characteristic } & $\begin{array}{c}\text { Gravel } \\
\text { pit 2 }\end{array}$ & $\begin{array}{c}\text { Gravel } \\
\text { pit 3 }\end{array}$ & \multicolumn{1}{c}{ Birch Creek Playa } \\
\hline $\begin{array}{l}\text { Water-surface elevation } \\
\text { at full-pool capacity, }\end{array}$ & $4,797.3$ & $4,788.7$ & 4,780 & 4,788 \\
in feet & & & & \\
Surface area, in acres & 3.9 & 29.7 & 1,030 & 8,140 \\
Volume, in acre-feet & 20.9 & 352.4 & 1,160 & 31,800 \\
Perimeter, in miles & .5 & 2.4 & 16 & 63 \\
Maximum depth, in feet & 12.6 & 20.0 & 16.4 & 24.4 \\
Mean depth, in feet & 5.3 & 11.9 & 1.1 & 3.9 \\
\hline
\end{tabular}

chosen because its contour encompassed all the playas (fig. 1). At an elevation of $4,780 \mathrm{ft}$, the surface area of water in the playa is 1,030 acres and the volume is 1,160 acre-ft (table 1 and fig. 3). Past investigators usually delineated Birch Creek Playa at the 4,780-ft contour. The relations among elevation, surface area, and volume are shown in figure 3.

Elevation values presented in table 1 and figure 3 differ from those of Niccum (1973, p. 13, fig. 3B-3) because his elevations were from topographic maps, whereas elevations used in this study were from DEM data. For example, Niccum (1973, p. 13, fig. 3B-3) estimated that at an elevation of $4,788 \mathrm{ft}$, Birch Creek Playa contains 18,200 acre-ft of water, about 13,600 acre-ft less than the estimate used in this study. Niccum (1973, p. 13, fig. 3B-3) estimated that at an elevation of 4,780 $\mathrm{ft}$, the playa contains about 1,100 acre- $\mathrm{ft}$ of water, similar to the estimate used in this study.

\section{DATA COLLECTION}

The computer model used to simulate 100-year peak flow water-surface elevations, described later in this report, required definition of channel and floodplain geometry and roughness coefficients for each of a series of cross sections in the study area. Cross-section geometry was defined by a series of land-surface elevation data measured at variably spaced distances from a reference point along section lines perpendicular to the direction of flow. In June 1995 and May 1996, U.S. Geological Survey personnel surveyed Birch Creek and diversion channels from about $4 \mathrm{mi}$ northwest of State Highway 22 to gravel pits 2 and 3 near Birch Creek Playa (fig. 2). Twenty-six channel cross sections were surveyed: 9 on creeks, 12 on diversion channels, and 


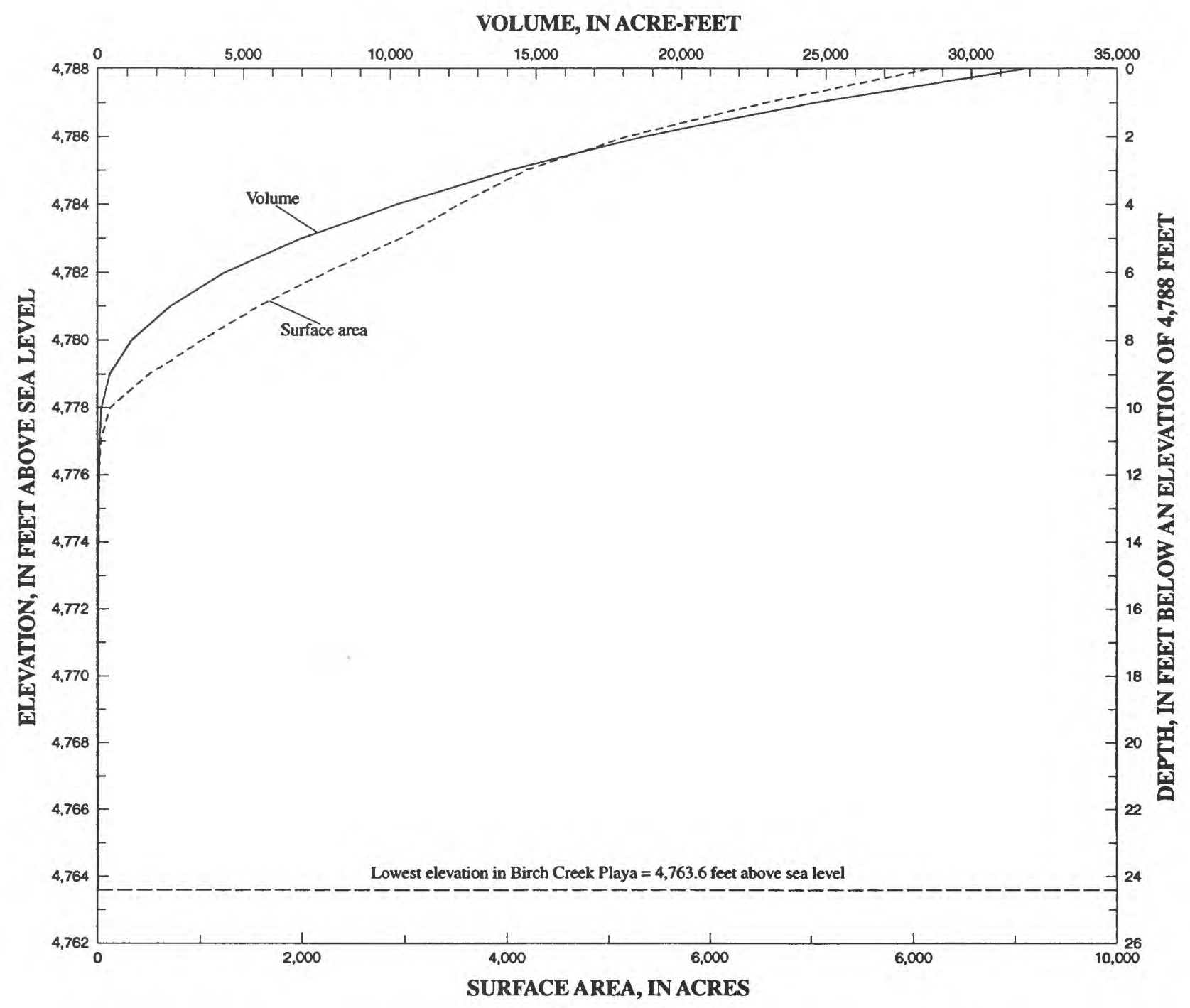

Figure 3. Relations among elevation of land surface, depth below a given elevation, surface area, and volume of Birch Creek Playa.

5 on the dirt road. One culvert near cross-section 5 and the highway near cross-sections 5 and 18 also were surveyed. Each cross section was located to best represent the hydraulic characteristics of that part of the creek, and each diversion channel and road section was surveyed to define its shape.

Channel roughness coefficients (Manning's $n$ ) were assigned for each cross section at the time of survey and were based on best engineering judgment. Roughness coefficient represents the resistance to openchannel flow. Factors that affect the roughness coefficient include (1) the type and size of materials that compose the streambed and banks, (2) shape of the channel,
(3) variation in dimensions of adjacent cross sections, (4) riparian and aquatic vegetation, (5) structures, and (6) degree of meandering. Roughness values used in the hydraulic analysis ranged from 0.048 to 0.068 for the main channel, 0.054 to 0.074 for secondary channels and the flood plain, and 0.028 to 0.040 for the highway, diversion channels, and roads.

All cross-section data were based on a common datum. Horizontal control was based on North American Datum of 1927 (NAD 27), State Plane Coordinates, Idaho East Zone, in feet; vertical control was based on the National Geodetic Vertical Datum of 1929 (sea level), in feet. Horizontal and vertical controls for the 
surveys were obtained with three Ashtech Z-12 geodetic GPS receivers. Two receivers (base stations) were located within several miles of a cross section over known geographically referenced points. Horizontal and vertical controls were surveyed at a minimum of three sites (hubs) at each cross section using the third GPS receiver. Also, known geographic reference marks were surveyed to ensure accuracy to one-hundredth of a foot in horizontal and vertical directions. Differential corrections were applied to all data collected with the GPS-a process called differential GPS.

\section{METHODS OF ANALYSIS}

Regional regression techniques were used to estimate 100-year peak flows in Birch Creek and its diversions (Kjelstrom and Berenbrock, 1996). The 100-year peak flow has a 1-percent chance of being equaled or exceeded in any given year. Although the recurrence interval represents the long-term average period between flows of a specific magnitude, rare peak flows could occur at shorter intervals or even within the same year.

A computer model was used to estimate watersurface elevations for the hypothetical 100-year peak flow in Birch Creek and its diversions. This model incorporated horizontal and vertical data collected along channel cross sections perpendicular to the direction of flow.

\section{Hydrologic Analysis}

Kjelstrom and Berenbrock (1996) estimated that the 100-year peak flow of Birch Creek at the INEEL boundary would be about $700 \mathrm{ft}^{3} / \mathrm{s}$. They further estimated that by the time water reached Birch Creek Sinks, the peak would be reduced to about $590 \mathrm{ft}^{3} / \mathrm{s}$ because of channel infiltration losses. Channel infiltration losses greater than $10\left(\mathrm{ft}^{3} / \mathrm{s}\right) / \mathrm{mi}$ have been measured along Birch Creek. However, Niccum (1973, p. 10-12) reported no loss of flow due to infiltration during the early part of the March-April 1969 flooding of Birch Creek. At that time, infiltration was blocked by frozen ground and (or) ice. Niccum (Aerojet Nuclear Company, written commun., 1973) also indicated that similar conditions greatly reduced channel infiltration along the Big Lost River during the floods of 1962 and 1965. Despite these observations, no infiltration losses were used in the model to provide for the worst case flooding scenario in the study area.

\section{Hydraulic Analysis}

Water-surface elevations of Birch Creek and its diversions were computed for the 100-year peak flow using the step-backwater computation model WaterSurface PROfile (WSPRO), developed by the USGS for the Federal Highway Administration (Shearman and others, 1986; Shearman, 1990). WSPRO is a computer program used to analyze one-dimensional, gradually varied, steady flow in open channels with fixed boundaries. The model uses the standard step method (Chow, 1959 , p. 265) to determine changes in water-surface elevation from one cross section to the next by balancing total energy head at the sections. The surveyed cross sections and assigned roughness coefficients defined channel and flood-plain hydraulic characteristics used in the model.

To simulate water-surface elevations, starting water-surface elevations at selected cross sections were determined from a slope-conveyance computation of normal depth. Water-surface elevations and roughness coefficients were adjusted from field estimates until the simulated water-surface elevation, velocity, and Froude number $(F=V / \sqrt{(g D)}$, where $F$ is Froude number; $V$ is mean velocity of flow, in feet per second; $g$ is acceleration of gravity, in feet per second squared; and $D$ is hydraulic depth, in feet) were reasonable because no flow data were available to calibrate the model. Where sections crossed more than one channel, total flow was distributed among all channels (Kjelstrom, 1992, p. 6-8). WSPRO apportions 5 percent of the total flow to each of 20 equal-conveyance tubes. Thus, initial discharge values for each channel were computed from the apportioned discharge for the cross section. Kjelstrom (1992) used this method to apportion flow in channels around islands in the Snake River. He showed that flows apportioned by WSPRO were similar to flows measured with a current meter. Final flows were determined by adjusting roughness coefficient values within reasonable limits. Because changing roughness coefficient changes flow, model calibration for each channel along a cross section required adjustment of values until the simulated water-surface elevation, velocity, and Froude number were reasonable. Where multiple channels were present, simulated water-surface elevation was different for each channel. 
A culvert analysis program (Fulford, 1995) was used to compute flow through the culvert under State Highway 22. The program computes flow from upstream and downstream water-surface elevations along with culvert geometry and roughness.

\section{SIMULATION OF WATER-SURFACE ELEVATIONS}

Water-surface elevations for 100-year peak flows were simulated with WSPRO. A flow of $700 \mathrm{ft}^{3} / \mathrm{s}$ was routed along the entire study reach and used to determine the water-surface elevation at each cross section. Channel infiltration losses were assumed to be zero to provide for the worst case flooding scenario in the study area.

Flows were simulated with and without the culvert under State Highway 22 and with all flow in the channel nearest the right bank. The latter simulation was done because the channel nearest the right bank along cross-sections 2 through 5 had the lowest streambed elevation and also was usually the widest. In that area, Birch Creek crosses southwest-sloping alluvial fans at the base of the Bitterroot Range (fig. 1). Downstream from the fans, the primary channel of Birch Creek is flanked on both sides by secondary channels at higher elevations. Water-surface elevations and flows were determined for primary and secondary channels. Maximum flow capacities were determined for the diversion channels and roads because they probably would be at full capacity during peak flow. The assumption was made that no channels would be breached during the 100-year peak flow.

\section{Cross-Sections 1 Through 4}

A peak flow of $700 \mathrm{ft}^{3} / \mathrm{s}$ was simulated at crosssections 1 through 4 (fig. 2) because that reach is not affected by the culvert under State Highway 22, and stream channels have not been altered by construction of roads, dikes, or diversion channels. Simulation results are shown in figure 4 as land- and water-surface elevations and flow rates. For sections with more than one channel, simulated flow was confined within one channel and also was distributed among channels. Resultant water-surface elevations in different channels of a section were equal or near equal; flow differences are shown in figure 4. Peak flows at cross-sections 1 through 4 were confined within stream channels even when all flow was routed through the channel nearest the right bank (fig. 4).

\section{Cross-Section 5}

Peak flow in Birch Creek at cross-section 5 (about $225 \mathrm{ft}$ upstream from State Highway 22) is affected by the culvert under the highway and by the deepening and straightening of the main channel. Also, the banks were raised using materials excavated from the main channel. Flows in higher elevation channels along this section are diverted southwestward toward the culvert by a trench on the north side of the highway. Simulation indicated that flow capacity of the trench northeast of the culvert was about $400 \mathrm{ft}^{3} / \mathrm{s}$. Water reaching the culvert can (1) flow through the culvert, (2) continue down the trench on the north side of the highway, or (3) flow over the highway. Simulation indicated that water continued southwestward in the trench that parallels the highway when the water surface at the culvert was greater than $4,997.9 \mathrm{ft}$ - the lowest elevation of the right bank adjacent to the trench. Water flowed over the highway when water-surface elevation exceeded 4,999.7 ft. Flow capacity of the trench southwest of the culvert was about $450 \mathrm{ft}^{3} / \mathrm{s}$.

Simulation indicated that at peak flow $\left(700 \mathrm{ft}^{3} / \mathrm{s}\right)$, water flowed through the culvert, down the trench, and over the highway. At the culvert, the simulated water surface was $5,000.5 \mathrm{ft} ; 2.6 \mathrm{ft}$ higher than the right bank outlet to the trench and $0.8 \mathrm{ft}$ higher than the highway. Simulation indicated about $115 \mathrm{ft}^{3} / \mathrm{s}$ of water (16 percent of the total peak flow) flowed through the culvert, $385 \mathrm{ft}^{3} / \mathrm{s}$ (55 percent) flowed down the trench, and $200 \mathrm{ft}^{3} / \mathrm{s}$ (29 percent) flowed over the highway (fig. 5). Flow along the highway was confined to the trench. Simulated water-surface elevations are shown in figure 4 and the distribution of flow is shown in figures 4 and 5 .

If, during peak flow, the culvert were removed at the start of flooding and the resultant main channel had a trapezoidal shape (similar to channel 5 on cross-section 5, fig. 4) that was $8 \mathrm{ft}$ wide at the bottom and $20 \mathrm{ft}$ wide at the highway surface, model results (fig. 5) indicated that $450 \mathrm{ft}^{3} / \mathrm{s}$ of water flowed down Birch Creek, $135 \mathrm{ft}^{3} / \mathrm{s}$ more than if the culvert were in place. About $250 \mathrm{ft}^{3} / \mathrm{s}$ (36 percent) flowed in the main channel and $200 \mathrm{ft}^{3} / \mathrm{s}$ ( 29 percent) flowed over the highway. The 

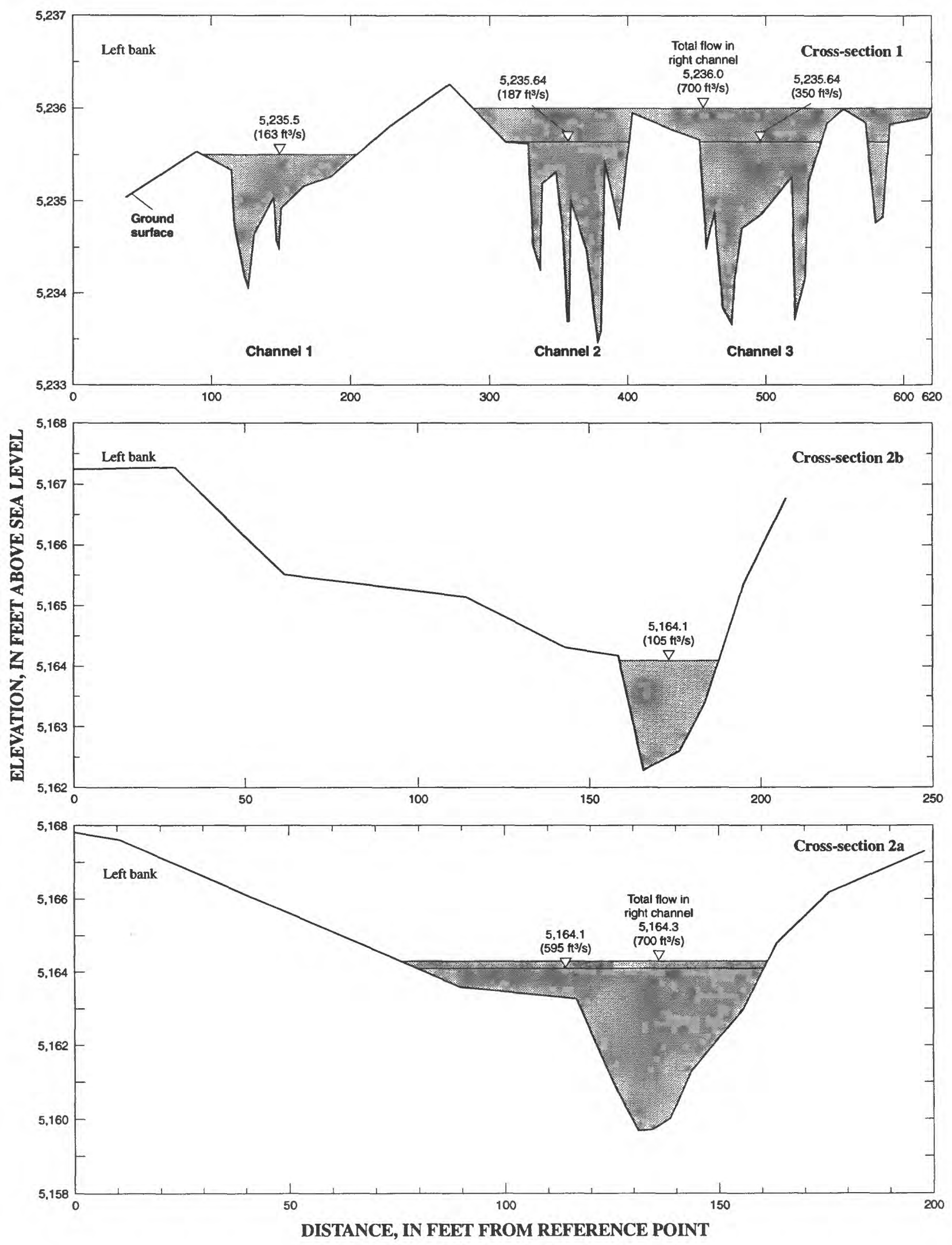

Figure 4. Water- and land-surface elevations, Birch Creek. (Locations shown in figure 2; $\mathrm{ft}^{3 / \mathrm{s}}$, cubic feet per second) 


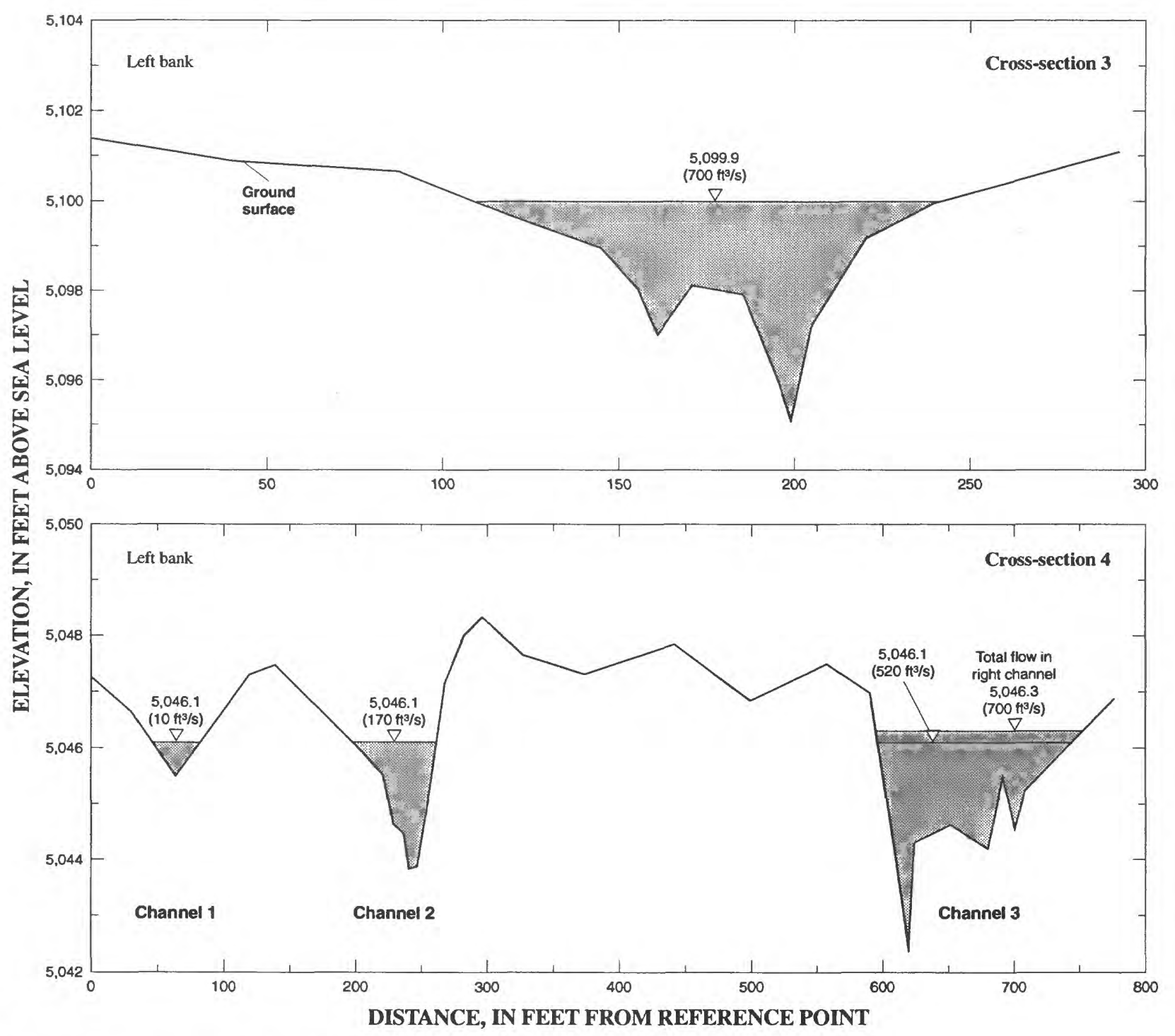

Figure 4. Water- and land-surface elevations, Birch Creek-Continued. 


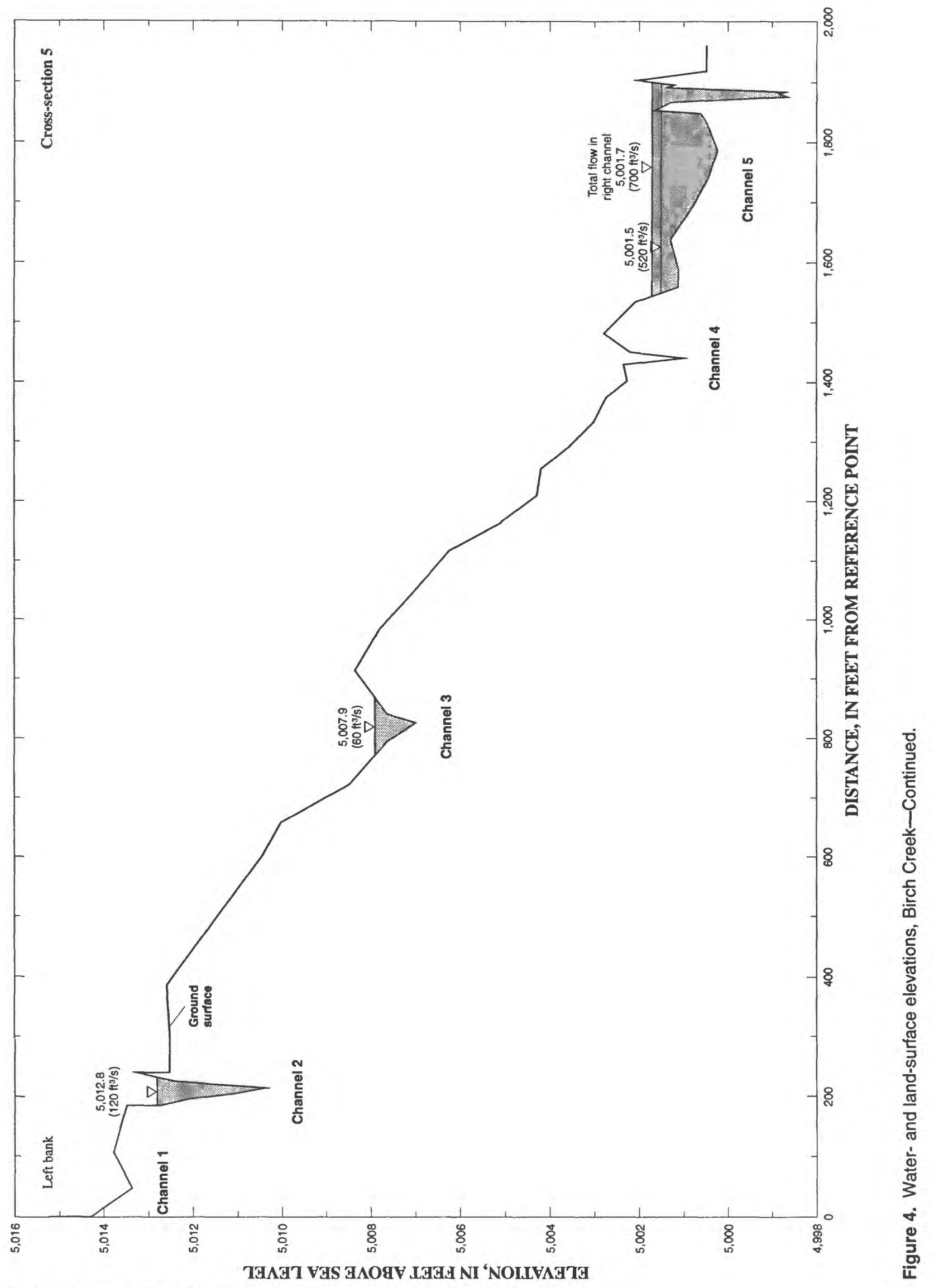




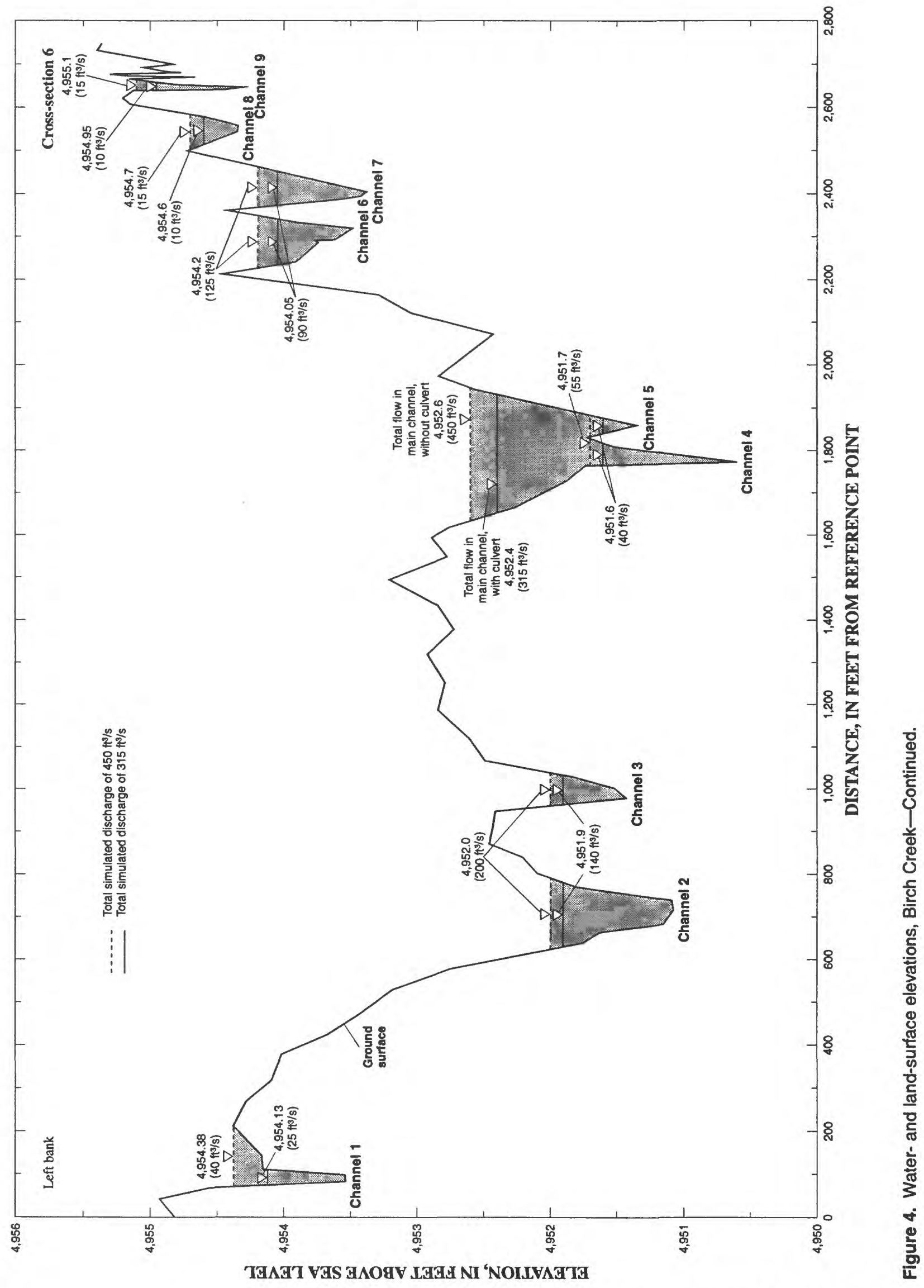



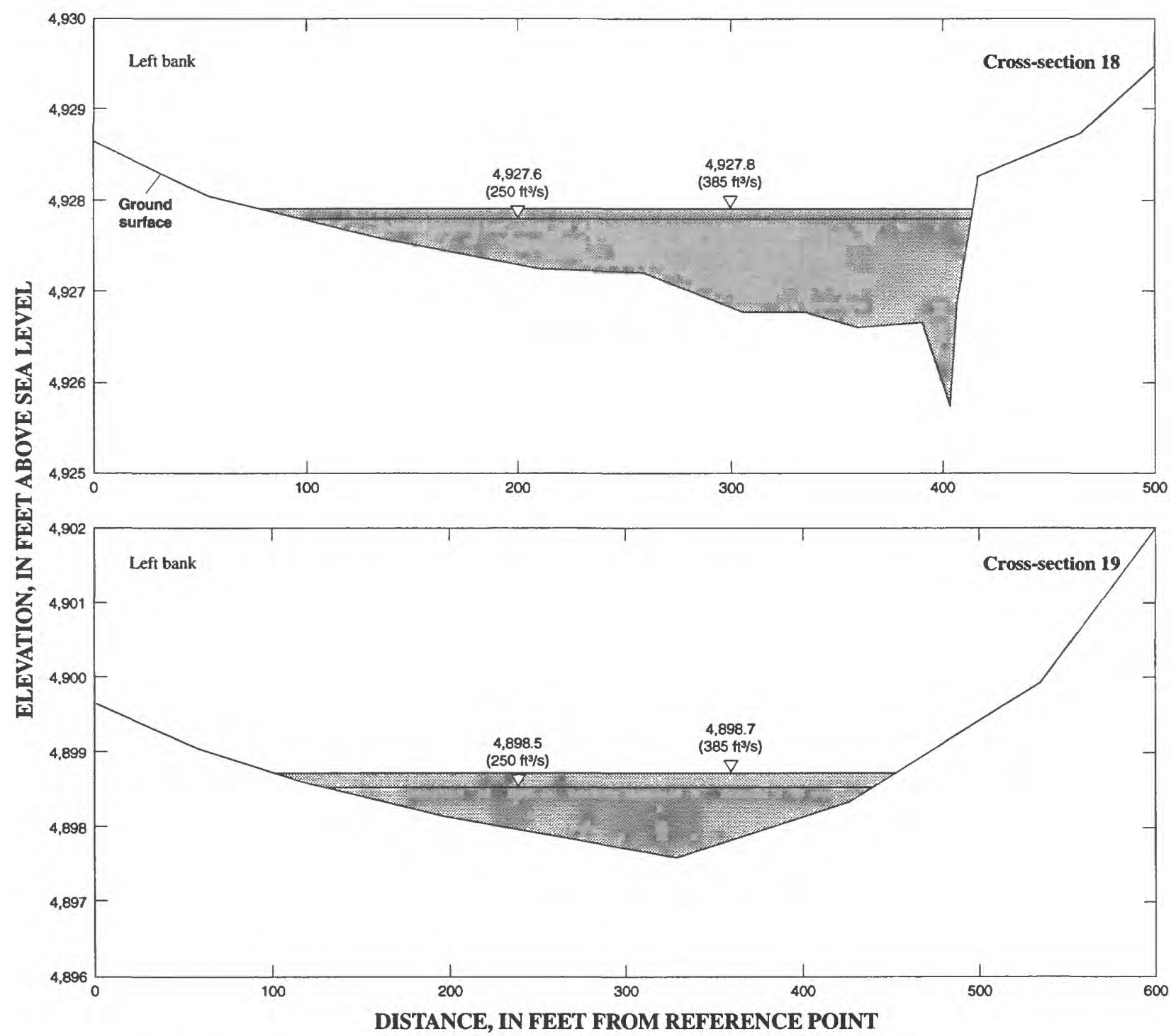

Figure 4. Water- and land-surface elevations, Birch Creek-Continued.

remaining $250 \mathrm{ft}^{3} / \mathrm{s}$ ( 36 percent) flowed southwestward in the trench that parallels State Highway 22.

\section{Cross-Section 6}

With the culvert in place, a peak flow of $315 \mathrm{ft}^{3} / \mathrm{s}$ (115 $\mathrm{ft}^{3} / \mathrm{s}$ of water through culvert plus $200 \mathrm{ft}^{3} / \mathrm{s}$ over highway) was simulated at cross-section 6 (figs. 4 and 5); with the culvert removed, flow increased to $450 \mathrm{ft}^{3} / \mathrm{s}$ and water-surface elevations were at least $0.1 \mathrm{ft}$ higher. The percentage of flow in each channel was about the same.

\section{Total Flow in Channel Having Lowest Streambed Elevation}

To study the effects of flooding within one channel, total flow was simulated in the channel with the lowest streambed elevation, which usually was the rightmost channel. Simulation indicated that the channel selected in cross-sections 2, 4, and 5 contained the entire peak flow of $700 \mathrm{ft}^{3} / \mathrm{s}$. At cross-section 1, flow was simulated in both the middle and right channels because the bank separating them was submerged at higher flows. Water-surface elevation was about $0.4 \mathrm{ft}$ 


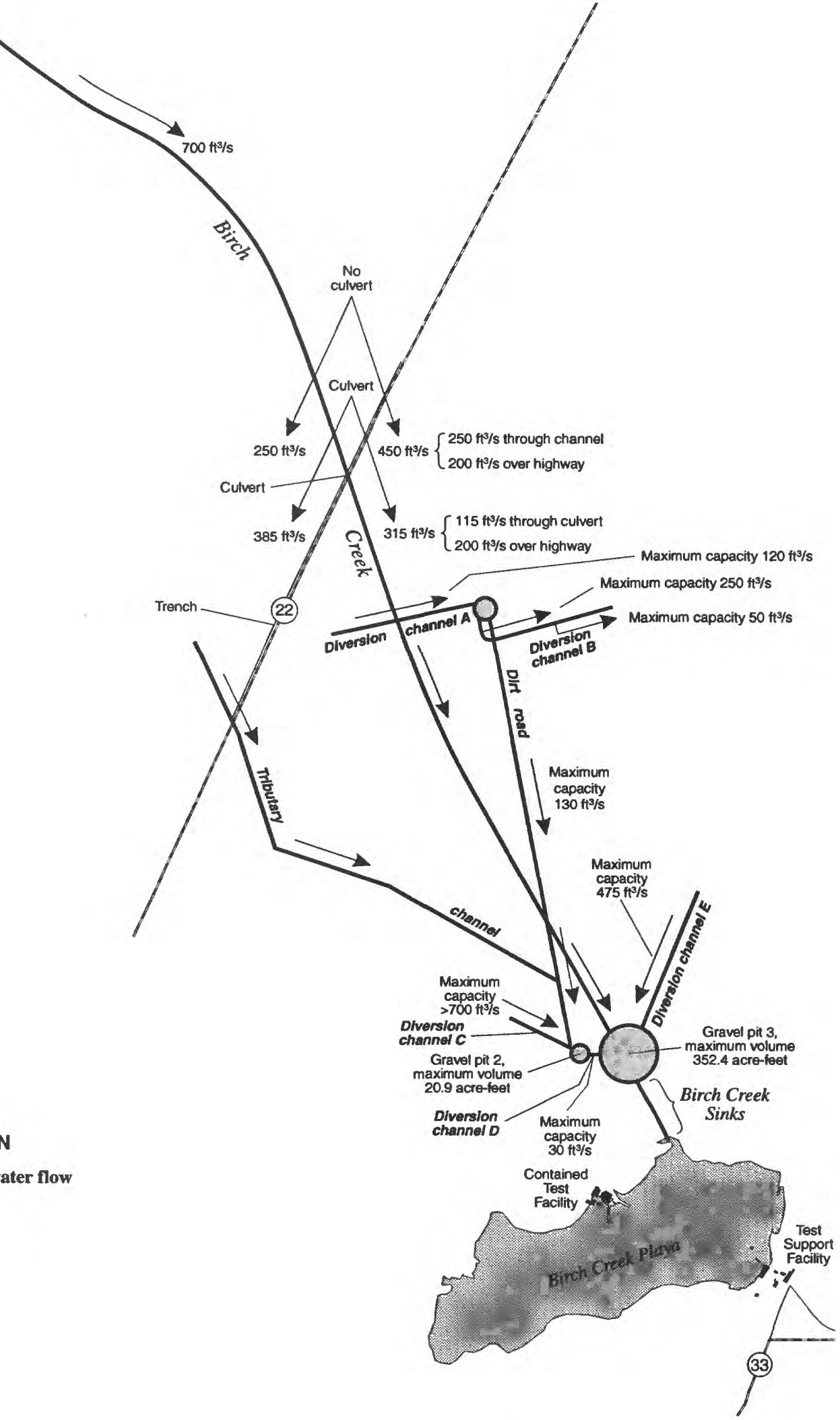

Figure 5. Peak flow in Birch Creek, maximum capacities of diversions, and volumes of gravel pits 2 and 3. ( $\mathrm{t}^{3 / \mathrm{s}}$, cubic feet per second) 
higher than when flow was distributed in all three channels (fig. 4). In cross-sections 2,4 , and 5, the water-surface elevation was about $0.2 \mathrm{ft}$ higher than when the flows were distributed.

At cross-section 6, channels 4 and 5 were combined and used to simulate a peak flow of $315 \mathrm{ft}^{3} / \mathrm{s}$ with the culvert and $450 \mathrm{ft}^{3} / \mathrm{s}$ without the culvert. Combining several channels was reasonable because the bank separating them was submerged at higher flows. When a flow of $450 \mathrm{ft}^{3} / \mathrm{s}$ was simulated, water-surface elevation was about $1 \mathrm{ft}$ higher than when the flows were distributed (fig. 4), channel depth doubled to about $2 \mathrm{ft}$, and channel width tripled to about $300 \mathrm{ft}$, compared with distributed flow results. Although large widths and small depths are characteristic of streams and washes in desert areas, flooding in Birch Creek at the magnitude simulated was confined within stream channels.

\section{Cross-Sections 18 and 19}

A tributary channel of Birch Creek also received flow because it is downstream and intersects the trench that parallels State Highway 22 in sec. 29, T. 7 N., R. 31 E. (fig. 2). This site is $75 \mathrm{ft}$ lower than where the highway crosses Birch Creek, $1.5 \mathrm{mi}$ to the northeast. There is no culvert or bridge at the site to permit water movement under Highway 22. Flow in the trench was estimated (see section "Cross-Section 5") to be $385 \mathrm{ft}^{3} / \mathrm{s}$ with the culvert in place and $250 \mathrm{ft}^{3} / \mathrm{s}$ with the culvert removed (fig. 5). At the highway and tributary channel, simulated water-surface elevation at a flow of $385 \mathrm{ft}^{3} / \mathrm{s}$ was $4,932.5 \mathrm{ft}, 0.9 \mathrm{ft}$ higher than the elevation of the highway; water-surface elevation at a flow of $250 \mathrm{ft}^{3} / \mathrm{s}$ was about $0.6 \mathrm{ft}$ higher than elevation of the highway.

Flows in the trench $\left(385 \mathrm{ft}^{3} / \mathrm{s}\right.$ and $\left.250 \mathrm{ft}^{3} / \mathrm{s}\right)$ were simulated for the tributary channel at cross-sections 18 and 19. Cross-section 18 is about $200 \mathrm{ft}$ downstream from the highway and cross-section 19 is about $0.8 \mathrm{mi}$ downstream. Simulation results are shown in figure 4. Both simulated flows at these sections were confined within the stream channel (fig. 4).

\section{Maximum Flow Capacities of Diversions}

Maximum flows were simulated in diversion channels because they intersect and divert water from Birch Creek. The southeast-trending dirt road (fig. 2) also was modeled as a diversion channel. Diversion
Table 2. Maximum flow capacities of diversions on Birch Creek

[Locations shown in figure 2; >, greater than]

\begin{tabular}{ccc}
\hline $\begin{array}{c}\text { Cross } \\
\text { section }\end{array}$ & $\begin{array}{c}\text { Diversion } \\
\text { channel }\end{array}$ & $\begin{array}{c}\text { Maximum flow capacity } \\
\text { (cubic feet per second) }\end{array}$ \\
\hline 7 & A & 120 \\
8 & B & 250 \\
9 & Dirt road & 30 \\
10 & B & 250 \\
11 & B & 50 \\
$12 \mathrm{a}$ & Dirt road & 120 \\
$12 \mathrm{~b}$ & Dirt road & 155 \\
13 & Dirt road & 150 \\
14 & Dirt road & 120 \\
15 & A & 180 \\
16 & A & 350 \\
17 & A & 150 \\
20 & C & $1>700$ \\
$21 \mathrm{a}$ & D & 30 \\
$21 b$ & D & 30 \\
22 & E & 475 \\
23 & E & 475 \\
\hline
\end{tabular}

${ }^{1}$ Water-surface elevation at a flow of 700 cubic feet per second is about 1.2 feet lower than the elevation of the top of the dike.

channel A, about $0.25 \mathrm{mi}$ downstream from crosssection 6, diverts water to gravel pit 1 (fig. 2). Crosssections $7,15,16$, and 17 are on diversion channel $A$. Simulated maximum flow capacities of diversion channel $A$ in cross-sections $7,15,16$, and 17 were 120,180 , 350 , and $150 \mathrm{ft}^{3} / \mathrm{s}$, respectively (table 2 ). The reason for the large difference in capacity between cross-section 16 and the other cross sections along diversion channel $A$ is that the diversion channel was not constructed to specific engineering plans but was dug rapidly by bulldozers (Koslow, 1984, p. 24), making an irregularshaped channel. The reduction in flow capacity among sections 16,17 , and 7 caused water to flow over the right embankment, follow the natural slope southeastward, and be intercepted by the dirt road and (or) by diversion channels C, D, E, and (or) gravel pits 2 and 3 (fig. 2). The maximum flow capacity of diversion channel A to gravel pit 1 was $120 \mathrm{ft}^{3} / \mathrm{s}$. When a peak flow of $315 \mathrm{ft}^{3} / \mathrm{s}$ passed State Highway 22 (with culvert), 195 $\mathrm{ft}^{3} / \mathrm{s}$ flowed over diversion channel A because flow into gravel pit 1 was limited by cross-section 7 . When peak flow was $450 \mathrm{ft}^{3} / \mathrm{s}$ (without culvert), $330 \mathrm{ft}^{3} / \mathrm{s}$ flowed over diversion channel A. Estimated flows were based 
on the assumption that diversion channels were not eroded or breached during peak flow.

Cross-sections 8,10 , and 11 are on diversion channel $\mathrm{B}$, which routes water from gravel pit 1 to the desert in sec. 23, T. 7 N., R. 31 E. (fig. 2). Diversion channel $\mathrm{B}$ crosses the dirt road that carries water from the gravel pit southward. Water in diversion channel B will not readily flow down the dirt road because of a 2-ft-high embankment on diversion channel B at the crossing. A maximum flow capacity of $250 \mathrm{ft}^{3} / \mathrm{s}$ was simulated at cross-sections 8 and 10 , and $50 \mathrm{ft}^{3} / \mathrm{s}$ was simulated at section 11 (table 2). Flow capacity decreased between cross-sections 10 and 11 because of a gradual lowering of the right bank, which reduces flow area. The right embankment was about $2 \mathrm{ft}$ high at cross-sections 8 and 10 and $1 \mathrm{ft}$ high at section 11 . The reduction in flow capacity between sections 10 and 11 would cause water to flow down the dirt road (fig. 2) and (or) overtop the right embankment and follow the natural slope southeastward.

The southeast-trending dirt road (fig. 2) was considered a diversion channel because it is bounded by embankments and intersects Birch Creek. Embankments along the road are less than $1 \mathrm{ft}$ high. The road at cross-section 9 , north of diversion channel $\mathrm{B}$, could carry about $30 \mathrm{ft}^{3} / \mathrm{s}$ of water from gravel pit 1 . Simulated maximum flow capacities at cross-sections $12 \mathrm{a}$ and 14 were $120 \mathrm{ft}^{3} / \mathrm{s}$ and, at sections $12 \mathrm{~b}$ and 13 , about $150 \mathrm{ft}^{3} / \mathrm{s}$, at least four times greater than the capacity at section 9 (table 2 and fig. 5). Water overtopping the road embankments would follow the natural slope southeastward and could be intercepted by diversion channels $C$, $D, E$, and (or) gravel pits 2 and 3 . Water overtopping the dirt road embankments south of sec. 27, T. 7 N., R. 31 E., probably would be intercepted by diversion channel $\mathrm{E}$ and directed to gravel pit 3 (fig. 2). Some water could go around diversion channel $\mathrm{E}$ and reach Birch Creek Playa.

Simulated maximum flow capacity of diversion channel C where it enters gravel pit 2 (cross-section 20) was much greater than $700 \mathrm{ft}^{3} / \mathrm{s}$ (table 2), the 100-year peak flow. The capacity is so large because land surface on the left bank increases very slowly, creating a large flow area. Flow width on the left bank is about $1,000 \mathrm{ft}$ and carries about 68 percent of the flow. At a flow of $700 \mathrm{ft}^{3} / \mathrm{s}$, simulated water-surface elevation was about $1.2 \mathrm{ft}$ lower than the top of the dike, and flow width on the left bank was reduced to about $550 \mathrm{ft}$.

Cross-sections $21 \mathrm{a}$ and $21 \mathrm{~b}$ are on diversion channel $D$, which routes water from gravel pit 2 to gravel pit 3 (fig. 2) and is about $500 \mathrm{ft}$ long. Simulated maximum flow capacities at these sections were $30 \mathrm{ft}^{3} / \mathrm{s}$. Water could flow to the southeast and reach CTF, Birch Creek Playa, and (or) TSF if gravel pit 2 received more than $30 \mathrm{ft}^{3} / \mathrm{s}$ when full. If the channel were widened and deepened, greater volumes of water would be diverted to gravel pit 3 .

Diversion channel E, trending southwestward, diverts water from the desert north of TSF to the eastern extremity of gravel pit 3 (fig. 2). Cross-sections 22 and 23 are on diversion channel $\mathrm{E}$. A maximum flow capacity of $475 \mathrm{ft}^{3} / \mathrm{s}$ was simulated at sections 22 and 23 . Water overtopping the right embankment of this diversion channel probably would follow the natural slope southeastward toward Birch Creek Playa and TSF, skirting gravel pit 3 .

\section{GENERALIZED 100-YEAR FLOOD-PRONE AREAS}

Usually, the extent of flooding is delineated using the simulated water-surface elevation at each surveyed cross section and following the topographic contours between sections. Because Birch Creek is highly braided, and many anthropogenic features in the study area affect flood hydraulics and flow, standard techniques were not used to determine the exact location of flood boundaries. Because flood boundaries could not be located exactly, only a generalized flood-prone map resulting from a 100-year peak flow in Birch Creek was developed (fig. 6). In the reach from cross-sections 1 to 5 , peak flows were previously determined to be confined within the braided channels. At State Highway 22 and downstream, anthropogenic features caused peak flows to spread out and encompass large areas. If the anthropogenic features were not present, peak flows probably would be confined within the braided channels to the Birch Creek Playa under similar conditions upstream from Highway 22. The trench along State Highway 22 causes water to flow downstream and into the tributary channel that crosses the highway $(1.5 \mathrm{mi}$ southwest of Birch Creek). Diversion channel B probably would cause water to flow into the desert and southeastward toward TSF (fig. 6). 


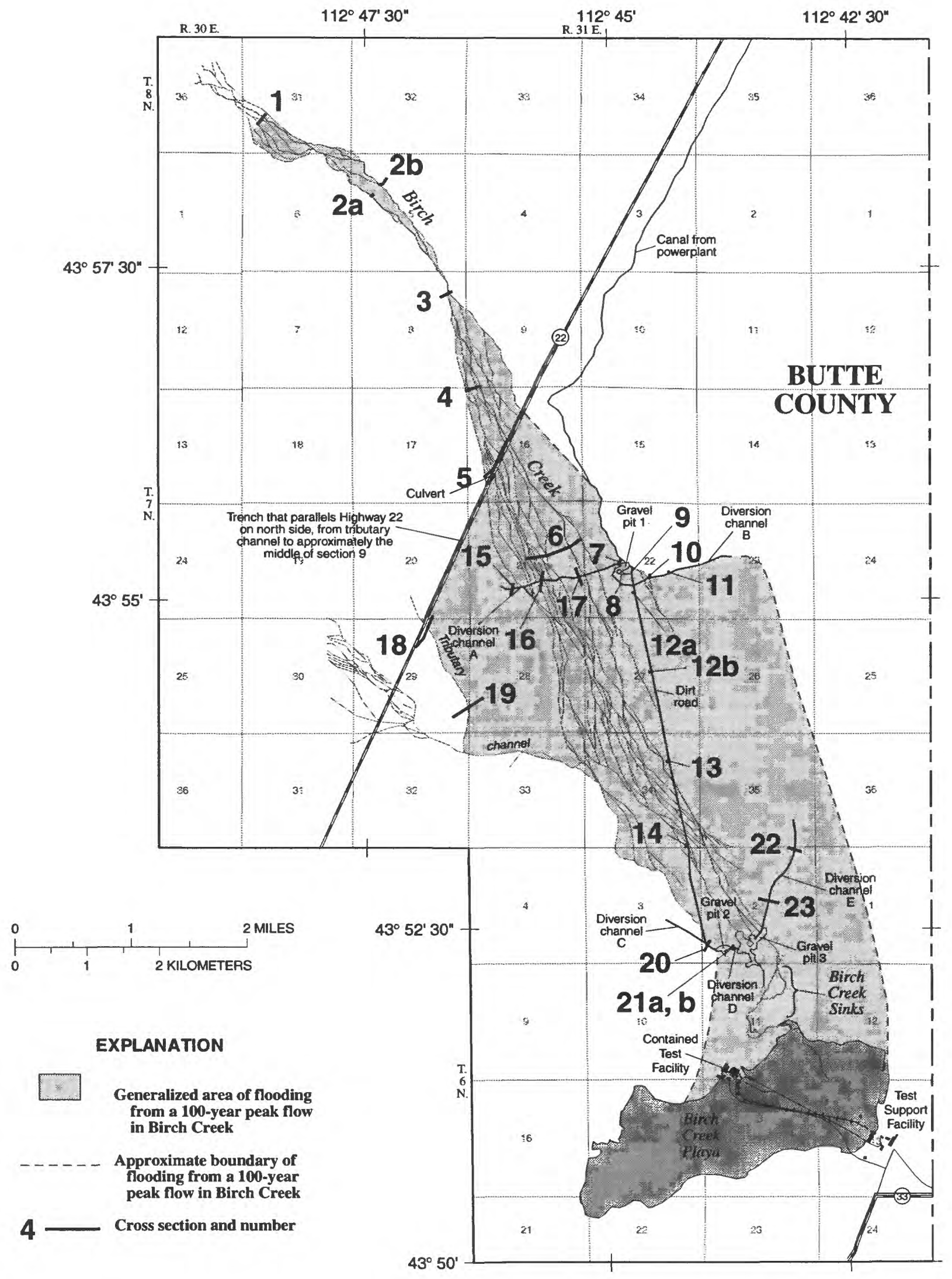

Figure 6. Generalized flood-prone areas resulting from a 100-year peak flow in Birch Creek. 


\section{SUMMARY}

This report describes results of a study to delineate the extent of possible flooding at the INEEL from a 100-year peak flow in Birch Creek.

Birch Creek flows southward about $40 \mathrm{mi}$ through an alluvium-filled valley to the eastern Snake River Plain. The study area is the lower 10-mi reach of Birch Creek that ends in Birch Creek Playa. Birch Creek is highly braided. Upstream from State Highway 22 , it crosses southwest-sloping alluvial fans. Streambed materials are largely coarse sand, gravel, and cobbles that are mined from three gravel pits in the study area. Birch Creek Playa is underlain by silt and clay.

Many anthropogenic features in the study area affect the flood hydraulics of Birch Creek. State Highway 22 crosses Birch Creek and its flood plain and may divert water southwestward in a trench along the highway. About 1 mi south of the highway, diversion channel A crosses the flood plain and routes water to gravel pit 1 . An outlet channel from gravel pit 1 routes water eastward to the desert. A 3.5-mi-long, southeast-trending dirt road also was considered a diversion because it crosses Birch Creek and can divert water southward toward CTF. At the southern end of the dirt road, diversion channel $\mathrm{C}$ can divert water to gravel pit 2 . Diversion channel $\mathrm{D}$ conveys water from gravel pit 2 to gravel pit 3, and diversion channel E conveys water southward to gravel pit 3 . If gravel pit 3 overflowed, water ultimately would flow to Birch Creek Sinks and Playa.

Geomorphic characteristics of gravel pits 2 and 3 and Birch Creek Playa were defined from DEM data. At full-pool capacity, gravel pit 2 has a water-surface area of 3.9 acres and a volume of 20.9 acre-ft; gravel pit 3 has a water-surface area of 29.7 acres and a volume of 352.4 acre-ft. With dikes at $4,786.5 \mathrm{ft}$, Birch Creek Playa has a water-surface area of 5,900 acres and a volume of 21,600 acre-ft. The water-surface elevation resulting from the 100 -year flow volume $(13,000$ acre$\mathrm{ft}$ ) is about $2 \mathrm{ft}$ lower than the elevation of dikes around TSF and CTF; therefore, no flooding of these facilities would be expected from the hypothetical 100 -year peak flow. If water-surface elevation were raised $1.5 \mathrm{ft}$ higher to $4,788 \mathrm{ft}$, surface area would increase to 8,140 acres and volume would increase to 31,800 acre-ft, more than twice the volume $(13,000$ acre-ft) that would result from the 100-year peak flow.

Cross-section data were needed to develop and apply a hydraulic model (WSPRO) to simulate water- surface elevations for a 100-year peak flow in Birch Creek. Twenty-six channel cross sections were surveyed: 9 on creeks, 12 on diversion channels, and 5 on the dirt road. One culvert near cross-section 5 and the highway near cross-sections 5 and 18 also were surveyed. Roughness values ranged from 0.048 to 0.068 for main creek channels, 0.054 to 0.074 for the flood plain, and 0.028 to 0.040 for the highway, diversion channels, and dirt roads. In the model, water-surface elevation and roughness values were adjusted until the simulated water-surface elevation, velocity, and Froude number were reasonable because no flow data were available to calibrate the model. Where cross sections crossed more than one channel, flow was distributed among all channels. The estimated 100 -year peak flow of Birch Creek at the northern boundary of the INEEL $\left(700 \mathrm{ft}^{3} / \mathrm{s}\right)$, was used in the hydraulic model.

Simulation indicated that flow upstream from Highway 22 was confined within channels even when all flow was routed through one channel. Where State Highway 22 crosses Birch Creek, about $315 \mathrm{ft}^{3} / \mathrm{s}$ of water flowed downstream from the highway $-115 \mathrm{ft}^{3} / \mathrm{s}$ through the culvert and $200 \mathrm{ft}^{3} / \mathrm{s}$ over the highway. The simulated water-surface elevation at this crossing was $0.8 \mathrm{ft}$ higher than the elevation of the highway. The remainder of the peak flow $\left(385 \mathrm{ft}^{3} / \mathrm{s}\right)$ flowed southwestward in a trench along the north side of the highway. The maximum flow capacity of the trench is about $450 \mathrm{ft}^{3} / \mathrm{s}$. With the culvert removed, about $450 \mathrm{ft}^{3} / \mathrm{s}$ of water flowed downstream $-250 \mathrm{ft}^{3} / \mathrm{s}$ through the breach on the highway and $200 \mathrm{ft}^{3} / \mathrm{s}$ over the highway. The remainder of the peak flow flowed southwestward in the trench.

A tributary channel southwest of Birch Creek receives flow because the channel is downstream and intersects the trench that parallels the north side of the highway. At the highway and tributary channel, the streambed elevation is $75 \mathrm{ft}$ lower than that where Birch Creek crosses the highway. Water flows over the highway at this site because there is no culvert or bridge to allow flow under the highway. The simulated water-surface elevation at this crossing was about $0.9 \mathrm{ft}$ higher than the elevation of the highway at a flow of $385 \mathrm{ft}^{3} / \mathrm{s}$ and about $0.6 \mathrm{ft}$ higher at a flow of $250 \mathrm{ft}^{3} / \mathrm{s}$. Simulation of tributary flow at cross-sections 18 and 19 indicated that both flows were confined within the channel, although flow widths are large.

Only maximum flow capacities were determined for diversion channels and the dirt road because they probably would be at full capacity during peak flow. 
Diversion channel A, 1 mi south of the highway, is perpendicular to Birch Creek and diverts water to gravel pit 1. The maximum capacity of diversion channel $A$ is about $120 \mathrm{ft}^{3} / \mathrm{s}$. If a flow of $450 \mathrm{ft}^{3} / \mathrm{s}$ passed State Highway 22 , about $330 \mathrm{ft}^{3} / \mathrm{s}$ would flow downstream from diversion channel $\mathrm{A}$ and some flow could be intercepted by the dirt road, diversion channels C, D, E, and (or) gravel pits 2 and 3 . Some water might flow eastward from the outlet of gravel pit 1 through diversion channel $\mathrm{B}$ and spread onto the desert. Initially, diversion channel B would carry $250 \mathrm{ft}^{3} / \mathrm{s}$; flow would gradually decrease to $50 \mathrm{ft}^{3} / \mathrm{s}$ as the channel area decreased because water would overflow the right embankment. The dirt road acts as a diversion channel because it is bounded by embankments and crosses Birch Creek. Maximum flow of the dirt road is from 120 to $150 \mathrm{ft}^{3} / \mathrm{s}$. Water overtopping the road embankments south of sec. 27, T. 7 N., R. 31 E., probably would be intercepted by diversion channel $\mathrm{E}$ and directed to gravel pit 3 before reaching Birch Creek Playa. Diversion channel C at the southern end of the dirt road diverts water to gravel pit 2 and can easily carry the 100 -year peak flow of $700 \mathrm{ft}^{3} / \mathrm{s}$. The maximum flow capacity for diversion channel D, between gravel pits 2 and 3 , was $30 \mathrm{ft}^{3} / \mathrm{s}$. If gravel pit 2 received more than $30 \mathrm{ft}^{3} / \mathrm{s}$ when full, areas to the southeast could be flooded. If the channel were widened and deepened, greater volumes of water would be diverted to gravel pit 3. Diversion channel E diverts water to gravel pit 3 and has a maximum capacity of about $475 \mathrm{ft}^{3} / \mathrm{s}$. Water passing this channel probably would flow toward Birch Creek Playa and TSF, skirting gravel pit 3.

Standard techniques to delineate the 100-year flood boundaries were not used on Birch Creek because it is extensively braided and anthropogenic features in the study area affect flood hydraulics and flow. However, generalized flood-prone areas were mapped. In reaches upstream from State Highway 22, flows were confined within the braided channels. At the highway and downstream, flows spread out and encompassed large areas, probably due to anthropogenic features such as the trench along State Highway 22 and diversion channel B. If the anthropogenic features were not present, peak flow probably would be confined within the braided channels of Birch Creek.

\section{REFERENCES CITED}

Bennett, C.M., 1990, Streamflow losses and ground-water level changes along the Big Lost River at the Idaho National Engineering Laboratory, Idaho: U.S. Geological Survey Water-Resources Investigations Report 90-4067, 49 p.

Berenbrock, Charles, Bassick, M.D., Rogers, T.L., and Garcia. S.P., 1995, Depth to water, 1991, in the Rathdrum Prairie, Idaho; Spokane River Valley, Washington; Moscow-Lewiston-Grangeville area, Idaho; and selected intermontane valleys, east-central Idaho: U.S. Geological Survey Water-Resources Investigations Report 94-4087, 2 sheets.

Chow, V.T., 1959, Open-channel hydraulics: New York, McGraw-Hill, $680 \mathrm{p}$.

Fulford, J.M., 1995, User's guide to the culvert analysis program: U.S. Geological Survey Open-File Report 95-137, 69 p.

Kjelstrom, L.C., 1992, Simulation of water-surface elevations for the Snake River in the Deer Flat National Wildlife Refuge, Idaho: U.S. Geological Survey WaterResources Investigations Report 91-4198, 105 p.

Kjelstrom, L.C., and Berenbrock, Charles, 1996, Estimated 100 -year peak flows and flow volumes in the Big Lost River and Birch Creek at the Idaho National Engineering Laboratory, Idaho: U.S. Geological Survey WaterResources Investigations Report 96-4163, 23 p.

Koslow, K.N., 1984, Hydrological characterization of Birch Creek Basin: Idaho Falls, EG\&G, Geosciences Section, Earth and Life Sciences Branch, EGG-PBS-6782, $29 \mathrm{p}$.

Niccum, M.R., 1973, Discussion of potential flood problems in conjunction with the LOFT program: Idaho Falls, Aerojet Nuclear Company, LTR 10-18, 20 p.

Shearman, J.O., 1990, User's manual for WSPRO- a computer model for water surface profile computations: U.S. Department of Transportation, 177 p. [available from the National Technical Information Service, U.S. Department of Commerce, Springfield, Va., 22161 as Report No. FHWA-IP-89-027].

Shearman, J.O., Kirby, W.H., Schneider, V.R., and Flippo, H.N., 1986, Bridge waterways analysis modelresearch report: U.S. Department of Transportation, 112 p. [available from the National Technical Information Service, U.S. Department of Commerce, Springfield, Va., 22161 as Report No. FHWA/RD-86/108].

Whitehead, R.L., 1986, Geohydrologic framework of the Snake River Plain, Idaho and eastern Oregon: U.S. Geological Survey Hydrologic Investigations Atlas HA-681, 3 sheets, scale 1:1,000,000. 